\title{
The Influence of Diets Containing Phenols and Condensed Tannins on Protein Picture, Clinical Profile and Rumen Characteristics in Omani Sheep
}

\author{
Osman Mahgoub ${ }^{a \star}$, Isam T.Kadim ${ }^{a}$, Hamza A. Babiker ${ }^{b}$ and Mohammed N. Al-Kindi ${ }^{b}$ \\ ${ }^{a}$ Department of Animal and Veterinary Sciences, College of Agricultural and Marine Sciences, \\ ${ }^{b}$ Department of Biochemistry, College of Medicine \& Health Sciences, Sultan Qaboos \\ University, P.O. Box: 34, PC 123, Al-Khod, Muscat, Sultanate of Oman. ${ }^{\star}$ Email: \\ osmahgob@squ.edu.om.
}

\begin{abstract}
A study was carried out to investigate the effects of feeding low quality non-conventional feeds (NCF) containing phenols and condensed tannins on health and performance characteristics in Omani sheep. Twelve Omani sheep were fed one of two base roughages, urea-treated palm frond (UTPF) or Rhodesgrass hay, (RGH) plus a commercial concentrate for 63 days. Haematological, serum biochemical and urine analyses were used to assess sheep health. Serum protein fractions were measured using electrophoresis. Urea-treated palm frond contained higher levels of polyphenols and condensed tannins and fiber than Rhodesgrass hay or concentrate feed. Animals fed UTPF had lower feed intake $(P<0.05)$ and lower body gain $(P<0.001)$ than those fed RGH. Rumen liquor of UTPF-fed animals had higher $\mathrm{pH}$, ammonia-nitrogen and butyric fatty acid but lower acetic fatty acid $(P<0.05)$. Animals fed UTPF had higher neutrophil $(P<0.05)$ but lower lymphocyte $(P<0.05)$ and monocyte $(P<0.001)$ counts by the end of the trial than those fed RGH. There were no effects of diet on serum albumin or globulin fraction levels or albumin:globulin ratio. There were no major effects on urine analysis but there was a trend by control animals to have higher protein and specific gravity than treated ones. This study indicated that feeding low quality non-conventional feeds containing polyphenols or tannins would reduce body gain and may produce some effects on clinical parameters. Although tannins are known to influence protein digestion and absorption in ruminants, it did not significantly affect the serum protein picture in sheep.
\end{abstract}

Keywords: Phenols; Tannins; Hematology; Protein; Sheep.

تأثير العلف المحتوي على الفينولات والتانين المكثف على صورة البروتين وصحة الحيوان وخصائص الكرش في الضأن العماني

$$
\text { عثمان محجوب ، عصام توفيق كاظم ، حمزة على بابكر ومحمد بن ناصر الكندي }
$$

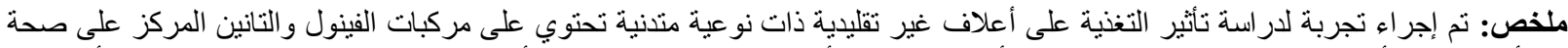

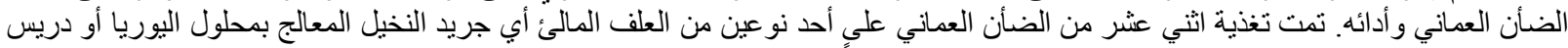

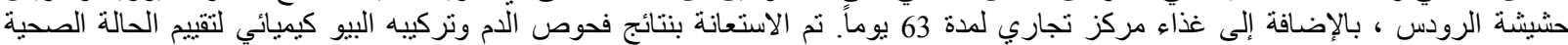

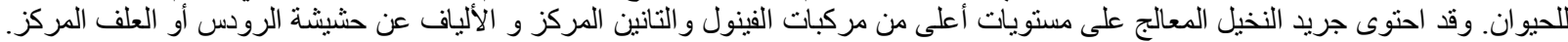

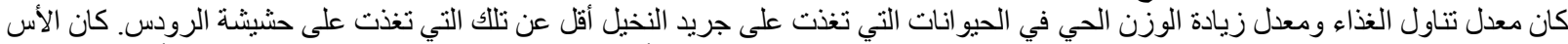

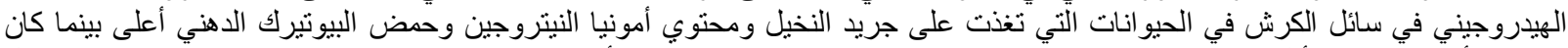

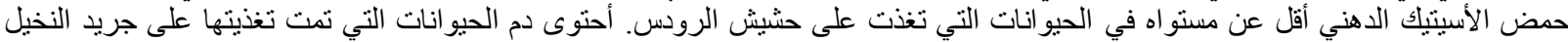

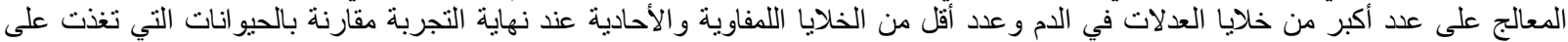

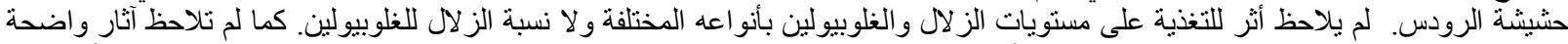

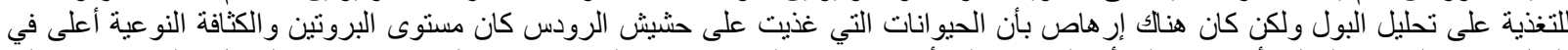

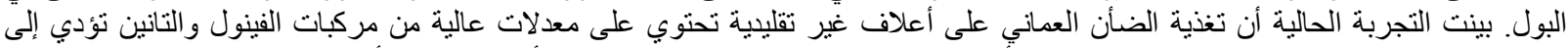

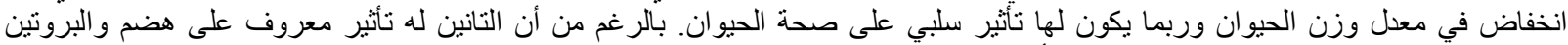

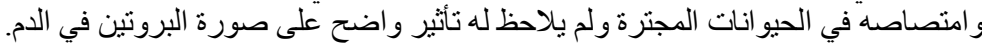

$$
\text { مفتاح الكلمات: مركبات الفينول، التانين، فحص الدم، البروتين، الضأن. }
$$




\section{INFLUENCE OF DIETS CONTAINING PHENOLS AND CONDENSED TANNINS}

\section{Introduction}

A nimals raised on natural range grazing in the dry tropics are customarily fed low quality non-conventional feeds such as agricultural by-products. These feeds are usually high in fibre and low in protein, minerals and vitamins. They may also contain secondary plant compounds such as polyphenols and condensed tannins which may have antinutritional effects [1]. Tannins which protect plants from degradation in the rumen are reported to significantly affect protein digestion and utilization. They form combinations with proteins in the rumen rendering them unavailable for digestion and consequently increasing their output in faeces [2,3]. In non-ruminants they interfere with nutrient digestion and promote excretion of endogenous nitrogen through the formation of tannin-enzyme complexes [4]. There are some reports that they might also cause physical damage to the digestive system [5] and other vital organs such as the kidney and liver [3]. However, there are no reports on the effects of these compounds on the blood protein picture.

Especially in growing animals, protein and amino acid metabolism which accounts for 20-30\% of whole body protein turnover and energy expenditure, is a function of the gastrointestinal tract tissues which amounts to only 3-6\% of body weight [6]. This is mainly because of their relatively high fractional rates of protein synthesis and oxygen consumption which is several fold higher than that of the peripheral tissues such as muscles [6]. Maintaining an adequate feed supply to the intestine orally is essential to maintain the intestine's major functions of digesting and absorbing nutrients and serving as a biological barrier against pathogens, toxins and antigenic molecules [6]. Therefore, the oral route is extremely important in this regard especially in young animals. For instance, in non-weaned pigs the input of amino acids from the luminal route is far greater $(67-90 \%)$ than the arterial circulation (11-21\%), particularly for glutamate and glutamine. Consequently, it might be hypothesized that agents which interfere with protein digestion and utilization, such as polyphenols and tannins, can influence the general protein picture including that of the serum. Electrophoresis is a useful technique for studying serum protein and it can provide useful information for determining the cause of increased, decreased or disproportion serum protein, which is usually related to an increase in immunoglobulin, except in cases of dehydration [7].

Feeding NCF to animals may not only reduce body weight growth rate but may also affect their health status and ability to withstand diseases. Macro (energy and protein) and micro (vitamin and mineral) malnutrition negatively affects the immune system, rendering animals more prone to diseases [8]. Feeding animals for extended periods on certain range land plants containing high levels of anti-nutritional compounds has been reported to produce detrimental effects on animal health $[9,10]$.

Studies on feeding feeds containing anti-nutritional factors mostly report effects on feed intake, body weight growth, digestibility of feeds, and rumen chemistry and biology. This study aimed to investigate the effects of feeding these feeds on the protein status, clinical profiles and rumen chemistry in sheep.

\section{Materials and Methods}

Twelve 1-year old male Omani native sheep (body weight $31.8 \pm 1.2 \mathrm{~kg}$ ) were used in a 63 -d feeding trial with a completely randomized experimental design including two types of roughages; Rhodesgrass hay and urea-treated palm frond. The animals were also fed a commercial concentrate beside the roughage. Animals were daily fed $300 \mathrm{~g}$ of the concentrate for the first month then $400 \mathrm{~g}$ thereafter plus ad libitum roughage. The UTPF was prepared by adding a $4 \%$ commercial urea solution to the chopped palm fronds and ensiling for 60 days. Water and mineral blocks were offered ad libitum. The blocks (Frank Wright Ltd., UK) contained $400 \mathrm{mg} / \mathrm{kg}$ cupric sulphite, $200 \mathrm{mg} / \mathrm{kg}$ manganous oxide, $120 \mathrm{mg} / \mathrm{kg}$ zinc oxide, $124 \mathrm{mg} / \mathrm{kg}$ BMP-cobalt carbonate, $190 \mathrm{mg} / \mathrm{kg}$ calcium iodate, $10 \mathrm{mg} / \mathrm{kg}$ BMP-sodium selenite. They also contained $36 \%$ sodium, $1.3 \%$ calcium, $0.23 \%$ phosphorus, $0.30 \%$ magnesium and $40,000 \mathrm{iu} / \mathrm{kg}$ Vitamin D3. Daily feed intakes were determined and animals were weighed bi-weekly.

The proximate chemical composition of the various components of feeds was determined according to the standard methods of AOAC [11]. Dry matter (DM) was determined by drying in an oven for 24 hours at $80{ }^{\circ} \mathrm{C}$ (method 934.01). Crude protein (CP) was determined using a Foss Tecator Kjeltec 2300 Nitrogen/Protein Analyser (method 976.05). Fat (EE) was determined by Soxhlet ether extraction of the dry sample, using petroleum ether (method 920.39). Ash content was determined by ashing samples in a muffle furnace at $500{ }^{\circ} \mathrm{C}$ for $24 \mathrm{hr}$ (method 942.05 ). Acid detergent fibre (ADF) was determined using cetyl trimethyl ammonium bromide (CTAB) and $1 \mathrm{~N}_{2} \mathrm{SO}_{4}$ as described by Roberston and Van Soest [12]. Neutral detergent fibre (NDF) was determined using sodium sulphite and sodium lauryl sulphate as described by Van Soest et al. [13]. Alpha amylase was not used to determine NDF. ADF was expressed with ash whereas NDF was expressed without ash. Calcium and phosphorus were measured with an atomic absorption spectrophotometer (Philips Model PU 9100, single beam). Gross energy (GE) was measured using a bomb calorimeter.

Levels of phenols and condensed tannins were analysed following the methods of Makkar [14]. Condensed tannins were determined by extracting $200 \mathrm{mg}$ samples overnight in $10 \mathrm{ml}$ aqueous acetone (70:30 acetone:water) solution at $4{ }^{\circ} \mathrm{C}$. After centrifugation $\left(3000 \times \mathrm{g}\right.$ at $4{ }^{\circ} \mathrm{C}$ for $\left.10 \mathrm{~min}\right)$, the supernatants were analysed for condensed tannins using leucocyanidin standard. Total extractable phenols are expressed as gram equivalent tannic acid per kilogram dry matter. Extractable condensed tannins are expressed as gram equivalent leucocyanidins per kilogram dry matter. 
The use of experimental animals and methodology for the trial was approved by the College of Agricultural and Marine Science Research Committee under Project number: SR/AGR/PINT/01/01.

Rumen liquor was collected at slaughter, strained and $\mathrm{pH}$ was recorded. Liquor was centrifuged and the clear top liquid used for the estimation of ammonia- $\mathrm{N}$ by reading against optical density at $540 \mathrm{~nm}$ in a UV-Visible spectrophotometer (Thermo Spectronic Corporation U.K.; Type Helios Beta Model).

Ten $\mathrm{mL}$ of blood samples were collected from each animal in plain glass vacutainers or with EDTA by jugular venipuncture on the last day of experiment. They were analyzed for: red blood cell count (RBC), packed cell volume (PCV), haemoglobin (HGB), mean corpuscular volume (MCV), mean cell haemoglobin (MCH) and mean cell haemoglobin concentration (MCHC) and differential white blood cell count (WBC) of Neutrophils, Lymphocytes, Basophils, Eosinophils and Monocytes using a CELL-DYN 3700 blood analyzer (CELL-DYN 3700; Abbott Laboratories Diagnostic Division, Abbott Park, IL 60064, USA). A Giemsa stained blood smear was prepared for each sample. Serum samples were analyzed for glucose, blood urea nitrogen (BUN), albumin, creatinine, total protein, alanine aminotransferase (ALT), gamma glutamyl transpeptidase (GGT), magnesium (Mg), calcium (Ca), phosphorus (P) and iron (Fe) by spectrophotometric analysis using a CX7/CX7 serum chemistry analyser (Synchron, Beckman).

Total protein quantification was carried out using the Bradford protein assay method which is a reliable procedure for determining the concentration of solubilized protein. It involves the addition of an acidic dye to a protein solution, and subsequent measurement at $595 \mathrm{~nm}$ with a spectrophotometer or microplate reader. A NanoDrop® ND1000 Spectrophotometer and bio-rad protein assay reagent were used to quantitate the total protein. Serum Protein Electrophoresis (SPE) was used to determine levels of two major protein groups, albumin and globulin in the blood serum. Using protein electrophoresis, these two groups can be separated into five smaller groups (fractions): Albumin, Alpha-1 globulin, Alpha-2 globulin, and Gamma globulin. The Paragon Electrophoresis System (Beckman, USA) was used to separate the two blood protein groups and the mobility pattern was visually interpreted and quantitated by densitometry at $600 \mathrm{~nm}$, on a Beckman APPRAISE densitometer, in which the relative percent of each protein fraction is calculated automatically.

Urine samples were collected at the end of the experiment using a syringe to collect urine directly from the urinary bladder. They were analysed for blood, urobilinogen, bilirubin, protein, nitrite, ketones, ascorbic acid, glucose, $\mathrm{pH}$, specific gravity and leucocytes using URYXXON® 200 equipment and Combi 11 urine strips.

Data were subjected to the analysis of variance [15] to study the effects of diet using the general linear models procedure [16]. Significant differences between treatment means were assessed using the least significant difference procedure at $P<0.05$ level.

\section{Results}

There were significant differences in chemical composition between the UTPF and Rhodesgrass hay. UTPF contained higher levels of fibre, ash, $\mathrm{Ca}$ and phosphorus but lower hemicellulose (Table 1). It also contained four times the total extractable phenols and much higher condensed tannins compared to the conventional feeds (Table 1).

Animals fed the UTPF consumed similar daily amounts of concentrates (Table 2) but less roughage than those fed RGH. The UTPF-fed animals gained less body weight over the experimental period ( $3 \mathrm{vs.} 70 \mathrm{~g} / \mathrm{d}$ ) than those fed the RGH. The UTPF-fed animals maintained their weight throughout the trial.

Haematological values of experimental animals were within normal values reported for sheep. However, animals fed the UTPF had higher neutrophil $(P<0.01)$ but lower lymphocyte $(P<0.01)$ and monocyte $(P<0.05)$ counts at the end of the trial compared to the RGH-fed animals (Table 3). There were no dietary effects on the serum biochemistry parameters measured (Table 3 ).

The serum protein profile is presented in Figure 1 and Table 4. Serum protein electrophoretograms exhibited a normal pattern. The serum albumin in treated and control sheep averaged $7 \mathrm{G} / \mathrm{dL}$, while the total globulin was 12.7 G/dL (Table 4).

The albumin proportion was higher (54\%), resulting in an albumin/globulin ratio of 1.3. Within the globulins, the highest proportion was made up of the Gamma globulins ( $3 \mathrm{G} / \mathrm{dL}, 24 \%)$ followed by Beta globulins $(9 \%)$ and Alfa 2 globulins (7.5\%), whereas the smallest proportion was made by Alpha 1 globulins (4.\%). However, there were no significant treatment effects on the various protein fractions. However, there was a consistent trend of treated animals having higher albumin and Gamma globulins (Table 4).

Visual examination had shown that urine from NCF-fed animals was turbid and brownish in colour. Urine analysis indicated a trend of elevated levels of protein, leukocytes and specific gravity in animals fed UTPF compared to those fed Rhodesgrass hay (Table 5). 


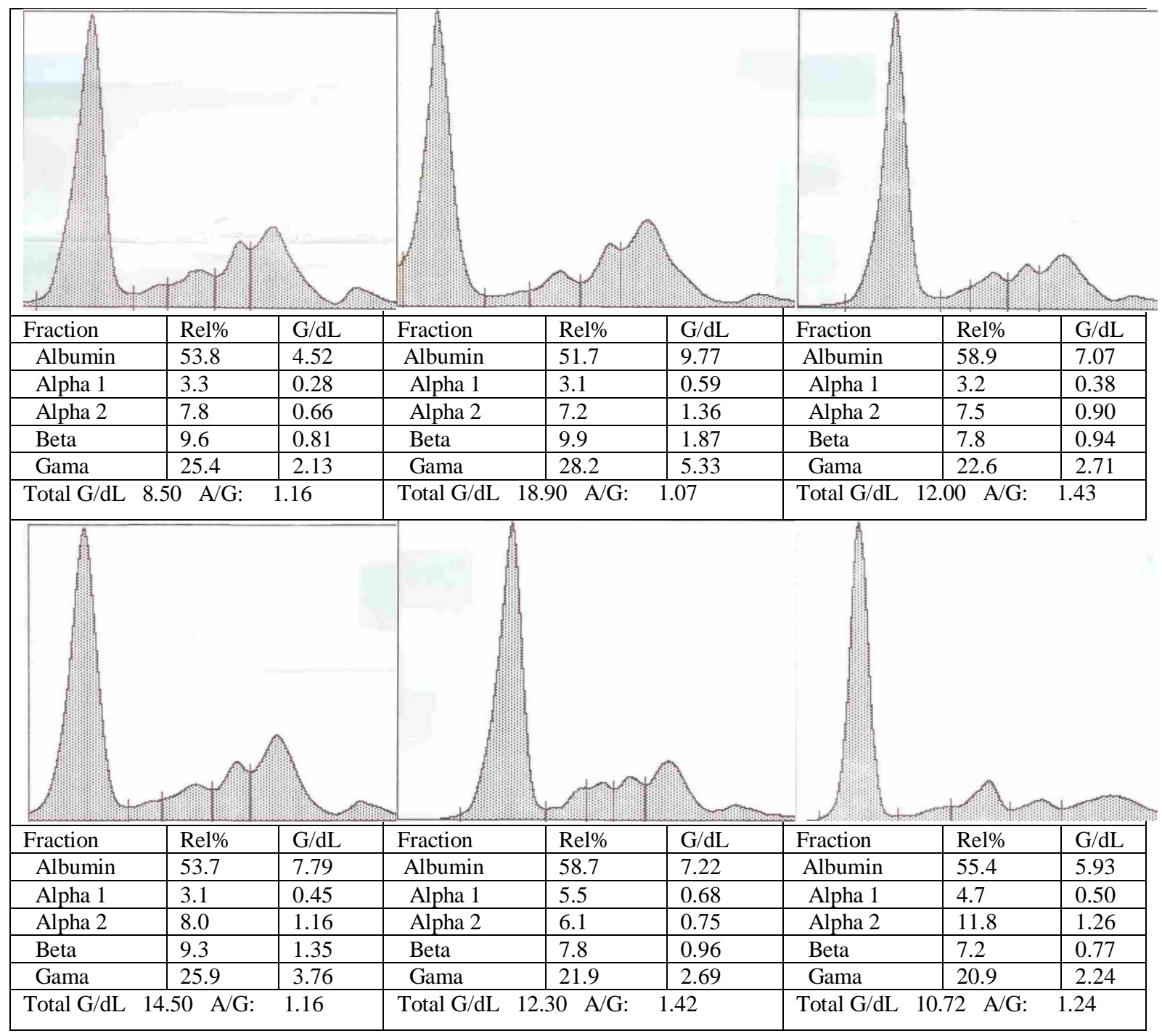

Figure 1. Serum protein electrophoretograms of Omani sheep fed Rhodesgrass hay (Control) and urea-treated palm frond (Treated) plus General Ruminant concentrate for nine weeks (Top row, treated animals; bottom row, control animals).

Table 1. Chemical composition of ingredients of experimental feeds.

\begin{tabular}{|c|c|c|c|}
\hline \multirow[t]{2}{*}{ Feed ingredient } & \multicolumn{3}{|c|}{ Experimental diets } \\
\hline & $\begin{array}{l}\text { Commercial } \\
\text { concentrate }\end{array}$ & $\begin{array}{l}\text { Urea-treated } \\
\text { palm frond }\end{array}$ & Rhodesgrass hay \\
\hline $\mathrm{DM}(\mathrm{g} / \mathrm{kg})$ & 862 & 892 & 916 \\
\hline Crude protein (g/kg DM) & 180 & 85 & 120 \\
\hline Ether extract (g/kg DM) & 21.5 & 11 & 15 \\
\hline Neutral detergent fiber ( $\mathrm{g} / \mathrm{kg} \mathrm{DM})$ & 182 & 740 & 614 \\
\hline Acid detergent fiber (g/kg DM) & 56 & 580 & 370 \\
\hline Hemicellulose (g/kg DM) & 126 & 160 & 243 \\
\hline Ash (g/kg DM) & 73 & 120 & 95 \\
\hline $\mathrm{Ca}^{++}(\mathrm{g} / \mathrm{kg} \mathrm{DM})$ & 12 & 7.4 & 5 \\
\hline $\mathrm{PO}_{4}(\mathrm{~g} / \mathrm{kg} \mathrm{DM})$ & 8 & 1.1 & 0.20 \\
\hline $\mathrm{GE}(\mathrm{kj} / \mathrm{g})$ & 183 & 192 & 173 \\
\hline Total extractable phenols ${ }^{\text {a }}$ & 16.6 & 112.6 & 32.1 \\
\hline Extractable condensed tannins ${ }^{b}$ & 0 & 12.8 & 0 \\
\hline
\end{tabular}

\footnotetext{
${ }^{\text {a }}$ Expressed as gram equivalent tannic acid/kg DM.
}

${ }^{\mathrm{b}}$ Expressed as gram equivalent leucocyanidins/kg DM. 
Animals on UTPF had higher rumen ammonia-N $(P<0.05)$ levels and their rumen $\mathrm{pH}$ was higher $(P<0.01)$ than those fed Rhodesgrass hay (Table 6). They also had significantly lower acetic acid but higher butyric fatty acids than the controls (Table 6).

Table 2. Feed intake and body weight gain of Omani sheep fed Rhodesgrass hay (Control) and those fed urea-treated palm frond (Treated) plus General Ruminant concentrate for nine weeks.

\begin{tabular}{lllll}
\hline Parameter & \multicolumn{2}{c}{ Treatment } & PSE & Effect of diet \\
\cline { 2 - 3 } & Treated & Control & & \\
\hline Number of animals & 6 & 6 & & \\
Days of experiment & 63 & 63 & & \\
Daily roughage intake $(\mathrm{g})$ & 554 & 696 & 38 & $*$ \\
Daily concentrate intake $(\mathrm{g})$ & 365 & 365 & 0 & $\mathrm{NS}$ \\
Daily feed intake $(\mathrm{g})$ & 919 & 1061 & 38 & $*$ \\
Starting body weight $(\mathrm{kg})$ & 31.60 & 31.88 & 0.519 & $\mathrm{NS}$ \\
Final body weight $(\mathrm{kg})$ & 31.70 & 35.92 & 0.837 & $* *$ \\
Average daily gain $(\mathrm{g})$ & 3 & 69 & 7 & $* * *$ \\
\hline
\end{tabular}

PSE, pooled standard error of means

NS, $\mathrm{P}>0.05 ; *, \mathrm{P}<0.05 ; * *, \mathrm{P}<0.01 ; * * *, \mathrm{P}<0.001$.

Table 3. Haematological and serum biochemistry values in Omani sheep fed diets containing phenols and tannins.

\begin{tabular}{|c|c|c|c|c|}
\hline \multirow[t]{2}{*}{ Parameters } & \multicolumn{2}{|c|}{ Experimental groups } & \multirow[t]{2}{*}{ PSE } & \multirow{2}{*}{$\begin{array}{l}\text { Effect of } \\
\text { diet }\end{array}$} \\
\hline & Treated & Control & & \\
\hline White blood cells $\left(\mathrm{X} 10^{3} / \mathrm{ml}\right)$ & 9.4 & 9.3 & 0.48 & NS \\
\hline Neutrophils (\% of WBC) & 61.1 & 46.9 & 1.82 & $* * *$ \\
\hline Lymphocytes (\% of WBC) & 30.0 & 39.9 & 2.24 & * \\
\hline Monocytes (\% of WBC) & 3.3 & 6.5 & 0.43 & $* * *$ \\
\hline Eosinophils (\% of WBC) & 1.7 & 1.8 & 0.44 & NS \\
\hline Basophils (\% of WBC) & 4.0 & 4.9 & 1.73 & NS \\
\hline Neutrophils $\left(\mathrm{X} 10^{3} / \mathrm{m}\right)$ & 5.8 & 4.4 & 0.42 & $*$ \\
\hline Lymphocytes $\left(\mathrm{X} 10^{3} / \mathrm{m}\right)$ & 2.8 & 3.9 & 0.24 & $*$ \\
\hline Monocytes $\left(\mathrm{X} 10^{3} / \mathrm{m}\right)$ & 0.3 & 0.6 & 0.04 & $* * *$ \\
\hline Eosinophils $\left(\mathrm{X} 10^{3} / \mathrm{m}\right)$ & 0.2 & 0.2 & 0.04 & NS \\
\hline Basophils $\left(\mathrm{X} 10^{3} / \mathrm{m}\right)$ & 0.3 & 0.5 & 0.14 & NS \\
\hline Red blood cells (X10 $/ \mathrm{ml})$ & 13.4 & 13.6 & 0.40 & NS \\
\hline Hemoglobin $(\mathrm{g} / \mathrm{ll})$ & 10.3 & 10.1 & 0.19 & NS \\
\hline Haematocrit $(\%)$ & 43.8 & 44.7 & 1.61 & NS \\
\hline Mean corpuscular vol. (fl) & 32.72 & 32.9 & 1.26 & NS \\
\hline Mean cell hemoglobin (pg) & 7.7 & 7.4 & 0.17 & NS \\
\hline Mean cell hemoglobin (pg) & 23.9 & 22.5 & 0.89 & NS \\
\hline $\mathrm{Ck}$ & 75.7 & 89.8 & 24.8 & NS \\
\hline GGT $(\mu / L)$ & 62.9 & 90.5 & 5.57 & NS \\
\hline $\operatorname{GOT}(\mu / \mathrm{L}))$ & 95.8 & 120.4 & 11.20 & NS \\
\hline
\end{tabular}

PSE, pooled standard error of means

NS, $\mathrm{P}>0.05 ; *, \mathrm{P}<0.05 ; * *, \mathrm{P}<0.01 ; * * *, \mathrm{P}<0.001$.

\section{Discussion}

Feed composition analyses indicated that animals fed the urea-treated palm fronds were subjected to a lower nutritional regime compared to those fed the Rhodesgrass hay as the UTPF had much higher fibre contents than the RGH. UTPF has been reported to have lower digestibility coefficients and sheep fed on it produced larger volumes of faeces and had lower viscosity of gut contents, a characteristic of highly fibrous diets [17]. Moreover, the UTPF also contained higher levels of phenols and condensed tannins that are known to have anti-nutritional effects [18, 2]. This would have further reduced its nutritive value, resulting in animals consuming less feed and gaining less body weight. Although the nutritional insult was not severe enough to cause experimental animals fed the UTPF to lose body weight, the diet characteristics indicated that animals that consumed them had been subjected to malnutrition. Malnutrition was defined by [8] as an "inadequate or unbalanced diet, or a failure to absorb or assimilate dietary elements". If severe enough, malnutrition may produce detrimental effects on the animal body. These may include macronutrient 


\section{INFLUENCE OF DIETS CONTAINING PHENOLS AND CONDENSED TANNINS}

deficiencies that may lead to body cell mass depletion and micronutrient deficiencies that may impair body immune function [8].

Animals fed the UTPF would have ingested considerable amounts of condensed tannins as they had consumed approximately $550 \mathrm{~g} / \mathrm{d}$ of UTPF. Similar levels of condensed tannins in sheep have been shown to reduce protein degradation in the rumen and increase protein flow to the intestine [19,20]. A digestibility trial using UTPF with sheep [17], indicated classical features of tannin-containing feeds in ruminants. A higher level of nitrogen in the faeces (less nitrogen retention) is a characteristic of dietary tannins, which bind to proteins in the rumen and consequently reduce digestion and absorption in the gut [4,5,2]. Tannins also form complexes with carbohydrates and minerals and inhibit microbial and digestive processes in ruminants [2]. Therefore, the presence of condensed tannins in the UTPF in the current study could have resulted in depressed rumen digestibility [18].

The UTPF-fed animals had higher rumen $\mathrm{pH}$ values than those fed Rhodesgrass hay. Ammonia- $\mathrm{N}$ and $\mathrm{pH}$ are indicators of rumen fermentation efficiency. This suggests that these animals had lower fermentation levels, which produced less volatile fatty acids, especially acetic fatty acid, as confirmed by chemical analyses of rumen liquor. Contrary to the findings of Mahgoub et al. [17], ammonia nitrogen levels in the current study were higher in UTPF-fed animals than in Rhodesgrass-fed animals. This could mainly be attributed to the fact that palm fronds in the current experiment had been ensiled in a solution of higher urea levels (4\%) which must have increased non-protein nitrogen levels in the rumen. This was reflected in diet chemical composition. Higher nitrogen levels in the faeces are usually accompanied by lower urine nitrogen level, a characteristic of animals fed condensed tannins [H.P.S. Makkar, personal communication, 2007 and 17] most probably due to the higher proportion of nitrogen excreted through the faeces.

Generally the serum protein fractioning was of a normal picture, as indicated in the electrophoretograms and individual animal values. However, there was a pattern of lower albumin and higher globulin levels. Albumin, produced by the liver, is major protein within the blood, and its levels are reduced by malnutrition and chronic liver disease such as cirrhosis. It appears that the UTPF feeding did not produce enough insult to produce severe malnutrition or affect the liver of the experimental animals. Globulins play an important role in immunity (e.g., IgA, $\mathrm{IgG}, \mathrm{IgE}$ ). The trend of slightly higher globulins in treated animals may indicate some effects of tannins on the immune system, most probably indirectly through the leptin axis.

This lack of effect on the protein picture suggests that, although tannins are known to interfere with protein digestion and utilization [2,17], apparently they did not affect the serum protein pattern in the current study. This could be due to the lower dosages and levels of tannins and polyphenols used in the present study.

Table 4. Serum protein values in Omani sheep fed diets of urea-treated palm frond or Rhodesgrass hay plus a concentrate.

\begin{tabular}{|c|c|c|c|c|c|c|c|c|c|c|c|c|c|}
\hline ID & TRT $^{1}$ & $\begin{array}{c}\text { Albumin } \\
(\%)\end{array}$ & $\begin{array}{c}\text { Albumin } \\
(\mathrm{G} / \mathrm{dL})\end{array}$ & $\begin{array}{c}\text { Alpha 1 } \\
\text { globulins } \\
(\%)\end{array}$ & $\begin{array}{c}\text { Alpha 1 } \\
\text { globulins } \\
(\mathrm{G} / \mathrm{dL})\end{array}$ & $\begin{array}{c}\text { Alpha 2 } \\
\text { globulins } \\
(\%)\end{array}$ & $\begin{array}{c}\text { Alpha } 2 \\
\text { globulins } \\
(\mathrm{G} / \mathrm{dL})\end{array}$ & $\begin{array}{c}\text { Beta } \\
\text { globulins } \\
(\%)\end{array}$ & $\begin{array}{c}\text { Beta } \\
\text { globulins } \\
(\mathrm{G} / \mathrm{dL})\end{array}$ & $\begin{array}{c}\text { Gamma } \\
\text { globulins } \\
(\%)\end{array}$ & $\begin{array}{c}\text { Gamma } \\
\text { globulins } \\
(\mathrm{G} / \mathrm{dL})\end{array}$ & $\begin{array}{c}\text { Total } \\
\text { globulins } \\
(\mathrm{G} / \mathrm{dL}) \mathrm{L}\end{array}$ & $\begin{array}{c}\text { Albumin } \\
\text { Globulin } \\
\text { ratio }\end{array}$ \\
\hline 2380 & $\mathrm{~T}$ & 55.00 & 4.95 & 5.40 & 0.49 & 9.10 & 0.82 & 5.30 & 0.48 & 25.10 & 2.26 & 9.00 & 1.22 \\
\hline 2400 & $\mathrm{~T}$ & 51.70 & 9.77 & 3.10 & 0.59 & 7.20 & 1.36 & 9.90 & 1.87 & 28.20 & 5.33 & 18.90 & 1.07 \\
\hline 2442 & $\mathrm{~T}$ & 57.50 & 8.40 & 2.70 & 0.39 & 7.70 & 1.12 & 9.10 & 1.33 & 23.00 & 3.36 & 14.60 & 1.35 \\
\hline 2467 & $\mathrm{~T}$ & 53.80 & 4.52 & 3.30 & 0.28 & 7.80 & 0.66 & 9.60 & 0.81 & 25.40 & 2.13 & 8.40 & 1.16 \\
\hline 2470 & $\mathrm{~T}$ & 58.90 & 7.07 & 3.20 & 0.38 & 7.50 & 0.90 & 7.80 & 0.94 & 22.60 & 2.71 & 12.00 & 1.43 \\
\hline 2494 & $\mathrm{~T}$ & 58.00 & 7.83 & 4.50 & 0.61 & 3.80 & 0.51 & 7.70 & 1.04 & 26.10 & 3.52 & 13.50 & 1.38 \\
\hline Mean & & 55.82 & 7.09 & 3.70 & 0.46 & 7.18 & 0.90 & 8.23 & 1.08 & 25.07 & 3.22 & 12.73 & 1.27 \\
\hline 2401 & $\mathrm{C}$ & 55.30 & 6.91 & 6.20 & 0.78 & 5.50 & 0.69 & 8.00 & 1.00 & 24.90 & 3.11 & 12.50 & 1.24 \\
\hline 2420 & $\mathrm{C}$ & 55.40 & 5.93 & 4.70 & 0.50 & 11.80 & 1.26 & 7.20 & 0.77 & 20.90 & 2.24 & 10.70 & 1.24 \\
\hline 2466 & $\mathrm{C}$ & 53.70 & 7.79 & 3.10 & 0.45 & 8.00 & 1.16 & 9.30 & 1.35 & 25.90 & 3.76 & 14.50 & 1.16 \\
\hline 2471 & $\mathrm{C}$ & 49.90 & 8.03 & 7.00 & 1.13 & 10.00 & 1.61 & 12.20 & 1.96 & 20.90 & 3.36 & 16.10 & 1.00 \\
\hline 2486 & $\mathrm{C}$ & 46.00 & 4.69 & 3.10 & 0.32 & 8.50 & 0.87 & 18.30 & 1.87 & 24.20 & 2.47 & 10.20 & 0.85 \\
\hline 2495 & C & 58.70 & 7.22 & 5.50 & 0.68 & 6.10 & 0.75 & 7.80 & 0.96 & 21.90 & 2.69 & 12.30 & 1.42 \\
\hline Mean & & 53.17 & 6.76 & 4.93 & 0.64 & 8.32 & 1.06 & 10.47 & 1.32 & 23.12 & 2.94 & 12.72 & 1.15 \\
\hline PSE & & 1.53 & 0.69 & 0.55 & 0.09 & 0.85 & 0.14 & 1.32 & 0.20 & 0.86 & 0.38 & 1.29 & 0.07 \\
\hline Significance & & NS & NS & NS & NS & NS & NS & NS & NS & NS & NS & NS & NS \\
\hline
\end{tabular}

${ }^{1}$ TRT; $\mathrm{T}=$ treated (fed UTPF); $\mathrm{C}=$ control (fed Rhodesgrass hay)

PSE, pooled standard error of means

NS, $\mathrm{P}>0.05 ; *, \mathrm{P}<0.05 ; * *, \mathrm{P}<0.01 ; * * *, \mathrm{P}<0.001$

Although they did not gain much weight, UTPF-fed animals did not show explicit signs of disease such as diarrhoea, constipation or anorexia. This could be mainly attributed to genetic disease resistance in such animals of the arid tropics, which have been naturally selected over generations for survival and ability to utilize low quality feeds. However, negative health effects may be produced and go unnoticed in animals fed under similar systems. The lower 
lymphocyte and monocyte and lower neutrophil counts in animals fed UTPF could be an important indication of the health status of experimental animals. Monocytes are essential for the immune system as they are precursors of macrophages and lymphocytes essential for humoral and cell-mediated immunity responses. Similar findings had been reported by Mahgoub et al. [17].

Animals fed the UTPF had lower body weights compared to those fed RGH [21]. Although both control and treated animal groups started at similar weights $(32.5 \pm 1.13 \mathrm{~kg})$, the group of sheep fed the Rhodesgrass hay plus the commercial concentrate gained about $4 \mathrm{~kg}$ over the experimental period, whereas the UTPF-fed group maintained their body weight. This indicates that the latter group had a lower body condition score and consequently lower body fat reserves. Body composition may influence the immune system, with its effect most probably mediated by leptin [8]. Leptin is a $16 \mathrm{Da}$ protein produced by adipocytes and released into systemic circulation which acts as a master hormone controlling energy acquisition and utilization processes as well as the immune/inflammatory response [22]. Reduced level of leptin, a signal of energy reserve depletion (adipose tissue), appears to trigger the body to shut down non-essential body functions including those involved with immune and inflammatory responses [22]. Leptin influences lymphocyte proliferation and cytokine secretion [23]. This is in line with the low lymphocyte and monocyte counts in the current study. Pathological examination also indicated that animals fed UTPF had shown signs of chronic inflammation in the small intestine and nephritis, another sign of immune system compromise [3]. Low leptin levels caused by less adipose tissue in undernourished individuals reduced Th1 immune response resulting in increased susceptibility to infections [24].

The trend of higher levels of protein in the urine of control than in that of treated animals is in line with findings of Mahgoub et al. [17] and Makkar (personal communication , 2007), that animals fed higher levels of tannins tend to produce higher levels of nitrogen in the faeces and lower nitrogen levels in the urine. This is probably the cause of the trend of higher specific gravity of urine in these animals.

Table 5. Urine analyses of sheep fed urea-treated palm fronds containing higher levels of phenols and condensed tannins and those fed Rhodesgrass hay.

\begin{tabular}{|c|c|c|c|c|c|c|c|c|c|c|c|c|}
\hline $\operatorname{Diet}^{1}$ & ID No & $\begin{array}{l}\text { Blood } \\
\text { Ery } / \mu \mathrm{L}\end{array}$ & $\begin{array}{l}\text { Urobilinogen } \\
\mathrm{mg} / \mathrm{dL}\end{array}$ & Bilirubin & $\begin{array}{l}\text { Protein } \\
\mathrm{mg} / \mathrm{dL}\end{array}$ & $\mathrm{N}$ & Ketones & ASC & $\begin{array}{l}\text { Glucose } \\
\mathrm{mg} / \mathrm{dL}\end{array}$ & $\mathrm{pH}$ & $\begin{array}{l}\text { Specific } \\
\text { gravity }\end{array}$ & $\begin{array}{l}\text { Leucocytes } \\
\text { Leu/ } \mu \mathrm{L}\end{array}$ \\
\hline A & 2380 & 250 & norm & neg & neg & neg & neg & neg & neg & 5 & 1.000 & neg \\
\hline A & 2400 & 50 & norm & neg & neg & neg & neg & neg & neg & 5 & 1.000 & neg \\
\hline A & 2494 & 250 & norm & neg & 100 & neg & neg & neg & neg & 6 & 1.010 & neg \\
\hline A & 2470 & 250 & norm & neg & neg & neg & neg & neg & neg & 5 & 1.005 & neg \\
\hline A & 2442 & 50 & norm & neg & neg & neg & neg & neg & neg & 5 & 1.005 & neg \\
\hline B & 2486 & 250 & norm & neg & 100 & neg & neg & $1+$ & neg & 8 & 1.005 & 25 \\
\hline B & 2466 & 50 & norm & neg & 30 & pos & neg & neg & nor & 6 & 1.010 & neg \\
\hline B & 2495 & 250 & norm & neg & 100 & pos & neg & neg & neg & 7 & 1.015 & 75 \\
\hline B & 2401 & 250 & norm & neg & 30 & neg & neg & neg & neg & 5 & 1.015 & neg \\
\hline B & 2420 & 250 & norm & $1+$ & 100 & neg & neg & neg & neg & 5 & 1.025 & 25 \\
\hline B & 2471 & 50 & norm & neg & 100 & neg & neg & neg & neg & 8 & 1.010 & neg \\
\hline
\end{tabular}

${ }^{1}$ A: UTPF; B: Rhodesgrass hay
Norm: normal; neg: negative

Table 6. Rumen chemistry values in Omani sheep fed Rhodesgrass hay (Control) and those fed urea-treated palm frond (Treated) plus General Ruminant concentrate for nine weeks.

\begin{tabular}{lllll}
\hline Parameters & \multicolumn{2}{c}{ Experimental groups } & PSE & \multirow{2}{*}{ Effect of diet } \\
\cline { 2 - 3 } & Treated & Control & & \\
\hline $\begin{array}{lllll}\text { Rumen characteristics: } \\
\text { pH }\end{array}$ & 6.35 & 5.89 & 0.088 & $* *$ \\
Ammonia Nitrogen (mg/L) & 138.0 & 92.7 & 10.51 & $*$ \\
Volatile fatty acids & 1043 & & & \\
Acetic & 279 & 1399 & 116.9 & $*$ \\
Propionic & 92 & 222 & 44.6 & $\mathrm{NS}$ \\
Isobutyric & 231 & 75 & 7.1 & $\mathrm{NS}$ \\
Butyric & 51 & 145 & 42.7 & $*$ \\
Isovaleric & & 52 & 8.0 & $\mathrm{NS}$
\end{tabular}

PSE, pooled standard error of means

NS, $\mathrm{P}>0.05 ; *, \mathrm{P}<0.05 ; * *, \mathrm{P}<0.01 ; * * *, \mathrm{P}<0$. 


\section{INFLUENCE OF DIETS CONTAINING PHENOLS AND CONDENSED TANNINS}

\section{Conclusions}

In general the present study indicated that feeds containing anti-nutritional factors such as polyphenols and tannins, commonly fed to livestock around the world, may produce negative effects on livestock health, welfare and productivity. They appear to affect animal health in a combination of ways. Animals fed these feeds might have lower nutrient availability due to low digestibility resulting in macro and micro malnutrition. Malnutrition as a result of a combination of the above mentioned factors may result in lower body weight and consequently lower adipose tissue. This could result in a compromise of the body's immunity system, making the animal prone to infections and other ailments. The findings of this study did not show that there are significant effects of feeding sheep on diets containing tannins on the serum protein picture.

\section{Acknowledgment}

Mr. Musab Al-Busaidi, Mrs. Kanthi Annamalai and Mr. Khalid Al-Habsi of the department of Animal and Veterinary Sciences at Sultan Qaboos University provided technical help. Dr Hichem Ben Salem of INRAT, Tunisia, provided phenols and condensed tannin analyses.

\section{References}

1. Kumar, R. Anti-nutritional factors, the potential risks of toxicity and methods to alleviate them. FAO 102, Animal Production and Health Paper: 2005, pp.145-160.

2. Robins, C. and Brooker, J.D. The effects of Acacia aneura feeding on abomasal and intestinal structure and function in sheep. Anim. Feed Sci. \& Tech., 2005, 121, 205-215.

3. Longstaff, M. and McNab, J.M. The inhibitory effects of hull polysaccharides and tannins of field beans (Vicia faba L.) on the digestion of amino acids, starch and lipids and on digestive enzyme activities in young chicks. Brit. J. Nutr., 1991, 65, 199-216.

4. Mahgoub, O., Kadim, I.T., Tageldin, M.H., Al-Marzooqi, W.S., Khalaf, S.Q., Al-Amri, I. and Ambu, A.A. Pathological features in sheep fed rations containing phenols and condensed tannins. J. Anim. \& Vet. Adv., 2008b,7, 1105-1109.

5. Walton, J.P., Waghorn, G.C., Plaizier, J.C., Birtles, M. and Mcbridge, B.W. Influence of condensed tannins on gut morphology in sheep fed Lotus pedunculatus. Can. J. Anim. Sci., 2001, 81, 605-607.

6. Burrin, D.G. Gastrointestinal protein and amino acid metabolism in growing animals. In Biology of the Intestine in Growing Animals. Eds, Zabielski, R., Gregory, P.C. and Weström, B. Elsevier, Amsterdam. 2002, pp. 695-725.

7. Meyer, D.J. and Harvey, J.W. Veterinary Laboratory Medicine. Interpretation and Diagnosis. $3^{\text {rd }}$ Edition. Saunders, USA, 2004. Dekker, New York, Basel, 1981. pp. 123-158.

8. Hughes, S. and Kelly, P. Interactions of malnutrition and immune impairment, with specific reference to immunity against parasites. Parasit. \& Immun., 2006, 28, 577-588.

9. Adedapo, A.A., Adegbayibi, A.Y. and Emikpe, B.O. Some clinico-pathological changes associated with the aqueous extract of the leaves of Phyllanthus amarus in rats. Phytotherapy Res., 2005, 19, 971-976.

10. Tabosa, I.M., Souza, J.C., Graca, D.L. Barbosa-Filho, J.M., Almeida, R.N. and Rie Correa, F. Neuronal vacuolation of the trigeminal nuclei in goats caused by ingestion of Prosopis juliflora pods. Vet.\& Hum. Toxic., $2000,42,155-158$.

11. AOAC 2000. Official Methods of Analysis. (17 $7^{\text {th }}$ Edition), Association of Official Analytical Chemists. Gaithersburg, Maryland, 20877-2417. USA.

12. Roberston, J.B. and Van Soest, P.J. The detergent system of analysis, in: James, W.P.T. and Theander, O. (Eds.). The Analysis of Dietary Fibre in Food. Marcel Dekker, New York, Basel, 1981, pp. 123-158.

13. Van Soest, P.J., Roberston, J.B. and Lewis, B.A. Methods for dietary fibre NDF and non-starch polysaccharides in relation to animal nutrition. J. Dairy Sci., 1991, 74, 3583-3597.

14. Makkar, H.P.S. Quantification of tannins in tree and shrub foliage. A Laboratory Manual. Makkar H.P.S. (Ed.), Kluwer Academic Publishers., 2003, pp 102.

15. Ott, R.L. Analysis of variance in some standard experimental designs. In: Introduction to statistical methods and data Analysis. Duxbury Press, Belmont, CA. 1993, pp 842-928.

16. SAS Institute INC. SAS User's Guide: Statistics. Version 5, SAS Institute Inc., Cary, NC. USA, 1991.

17. Mahgoub, O., Kadim, I.T., Tageldin, M.H., Al-Marzooqi, W.S., Khalaf, S.Q. and Ambu, A.A. Clinical profiles of sheep fed non-conventional feeds containing phenols and condensed tannins. Small Rumin. Res., 2008a, 78, 115-122.

18. Perez-Maldonado, R.A. and Norton, B.W. The effects of condensed tannins from Desmodium intortum and Calliandra calothyrsus on protein and carbohydrate digestion in sheep and goats. Brit. J. Nutr., 1996, 76, 515533.

19. Waghorn, G.C., Jones, W.T. and Shelton, I.D. The nutritive value of Lotus corniculatus L. containing low and medium concentrations of condensed tannins for sheep. Proc.New Zealand Soc. Animal Production., 1987, 47, 7580. 
20. Waghorn, G.C. Effect of condensed tannin on protein digestion and nutritive value of fresh herbage. Proc. Aust. Soc. Animal Production., 1990,18, 412-415.

21. Mahgoub, O., Kadim, I.T., Al-Busaidi, M., Naseeb, H., Al-Saqri, M. and Annamalai, K. Effects of feeding ensiled date palm fronds and a by-product concentrate on performance and meat quality of Omani sheep. Anim. Feed Sci. \& Tech., 2007, 135, 210-221.

22. Fantuzzi, G. Nourishment for immune system. Euro. J. Immun., 2006, 36, 3101-3104.

23. Mattioli, B., Straface, E., Quaranta, M.G., Giordani and L. Viora M. Leptin promotes differentiation and survival of human dentritic cells and licenses them for Th1 priming. J. Immun., 2005, 174, 6820-6828.

24. Matarese, G., Moshos, S. and Mantzoros, C.S. Leptin in Immunology. J. Immun., 2005, 173, 3137-3142.

Received 2 October 2013

Accepted 11 December 2014 